\title{
Consumer Preferences for Sari Blouse and Scope for Readymade Sari Blouse
}

\author{
Ruby Kashyap Sood ${ }^{1}$, Dr. Suman Pant ${ }^{2}$ \\ ${ }^{1}$ (Department of Textile Design, National Institute of Fashion Technology, New Delhi, India) \\ ${ }_{2}^{2}$ (Department of Clothing \& Textile, Banasthali University, Rajasthan, India)
}

\begin{abstract}
The ethnic wear industry in India has grown rapidly over the past few years, presenting a variety of styles to meet the increasing needs of the modern Indian woman. The classic sari remains the most favoured traditional dress for women, and due to the increasing preference for ready-to-wear apparel, the readymade sari blouse is gaining precedence over a custom-stitched blouse. A consumer survey was conducted in Delhi/NCR to examine the blouse preferences of urban sari wearers in terms of fabric, fit and styling and ascertain scope for readymade sari blouse. A structured questionnaire was distributed to the sample and the responses were computed for statistical analysis. The consumer survey deduced the preference for readymade sari blouse by sari wearers in the age group of 20 to 40 years, keeping in view the convenience factor. The dissatisfaction with the existing readymade blouses was largely assigned to fitting and sizing problems, limited styles and garment quality.
\end{abstract}

Keywords - Consumer, Fit, Readymade, Sari Blouse, Style

\section{INTRODUCTION}

India displays a variety of both unstitched/draped and stitched clothing and the diversity in Indian attire can be attributed to the ethnic and regional variations within the country. The most typical attire that marks the identity of the Indian woman across the globe is the unstitched draped garment, sari that is teamed with the underskirt called the petticoat and a short fitted blouse known by various names in different parts of India. The most broadly used term for the blouse is the 'choli'. The other indigenous words for the blouse are 'ravikalu' in Andhra Pradesh, 'ravikkai' in Tamil Nadu and 'kuppas' or 'kupsa' from 'kurpasaka' in Karnataka [1].

The sari blouse is a tailored garment, and thus variations are possible in terms of sleeve length, neckline, bodice length, method of fastening and ornamentation [2]. The changing fashion over the $20^{\text {th }}$ century has witnessed a variety of style variations in the sari blouse. A myriad of styles, from modest necklines to halter necks and noodle straps, full length sleeves to sleeveless, in diverse fabrics like lace, georgette, knits, brocade and even leather are available for the young, modern women of today.

According to Gugnani \& Brahma (2014), the market for ethnic wear in India is likely to grow and reach US\$ 19,600 million by 2018 [3]. The booming ethnic wear market and the entry of different brands, designers and online stores catering to this segment have prompted the rise of the ready-to-wear garments. The preference for sari as a traditional attire has steered the demand for readymade sari blouses. The readymade sari blouse serves to be a suitable option for the economically independent women who have high purchasing power, but short of time to visit the local tailor.

The research attempts to study the consumer preferences for sari blouse and the preference for a readymade sari blouse over a custom-stitched blouse. The study also indicates problems experienced with the existing readymade sari blouses and concludes with suitable recommendations for the readymade garment industry.

\section{METHODOLOGY}

The quantitative approach was undertaken to conduct the consumer survey wherein structured questionnaire was distributed to urban sari wearers from Delhi and NCR. The non-probability sampling method was employed, wherein purposive and snowball sampling techniques were used. The sample included both regular and occasional sari wearers in the age group of 20 to 59 years, belonging to a higher socio-economic class. The responses obtained were coded and tabulated for data analysis and a combination of descriptive and inferential statistics was applied to determine the interrelationship among the defined variables. The Statistical Package for Social Sciences (SPSS) software, version 16.0 was employed for statistical analysis. To investigate the relationship between variables, hypotheses were formulated and cross-tabulations were conducted, that were verified for statistical significance through chi-square $\left(\chi^{2}\right)$ tests, followed by Cramer's V to examine the strength of association between the variables. Since the sample for consumer survey included respondents from different age groups of 20-29 years, 30-39 years, 40-49 years and 50-59 years, substantial cross-tabulations were 
performed to delve into the relationship between the age group of sari wearers and variables related to preference for sari blouse and readymade sari blouse.

\section{RESULTS AND ANALYSIS}

The consumer survey was undertaken by 390 respondents. Following data cleaning, a total of 277 respondents were selected for data analysis. The sample included urban sari wearers in the age group of 20 to 59 years. Majority of the respondents resided in Delhi while others were located in NCR, namely Noida, Gurgaon, Ghaziabad and Faridabad. The sample mainly comprised of married Hindu women. In terms of the level of education, nearly all the respondents were at least graduates, out of which a large number were postgraduates and above. The respondents were mostly working professionals including academicians and those employed in hospitality, health, media and design industries, alongside smaller percentage of homemakers, entrepreneurs and students. Most of the respondents indicated their annual family income as 12 lakhs and above and the remaining selected between 6 to 9 lakhs and 9 to 12 lakhs, and a small number stated between 3 to 6 lakhs and less than 3 lakhs. The sample thus belonged to the higher socio-economic class keeping in view their educational background and income level.

\section{Descriptive Statistics of Sari Blouse Preferences}

The distribution of respondents according to the importance of the sari blouse in comparison to the sari is detailed at Fig. 1.1. Majority of the sari wearers at $82.67 \%$ consider the blouse as important as the sari and $13 \%$ of the respondents give more importance to the blouse than the sari.

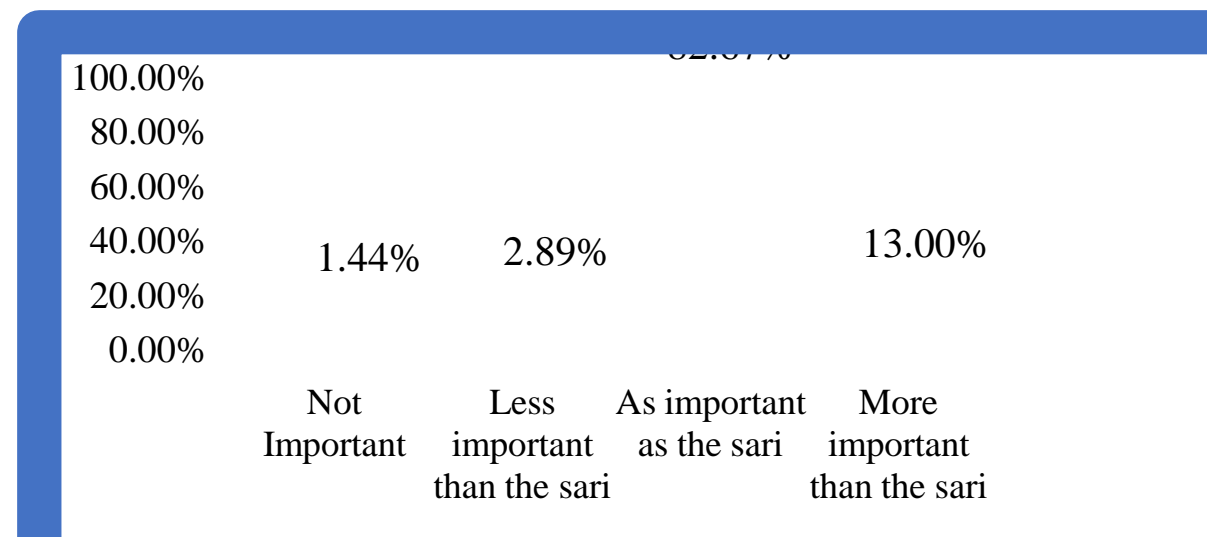

Figure 1.1: Importance of sari blouse

The respondents' preference for type of blouse piece is indicated at Fig. 1.2. It is ascertained that the blouse piece purchased separately to coordinate with the sari is chosen very frequently by $47.29 \%$ of the respondents and the blouse piece attached to the sari is preferred very frequently by $34.30 \%$ of the respondents. It is determined that wearers prefer to purchase the blouse piece separately more frequently than using the blouse piece attached to the sari. 


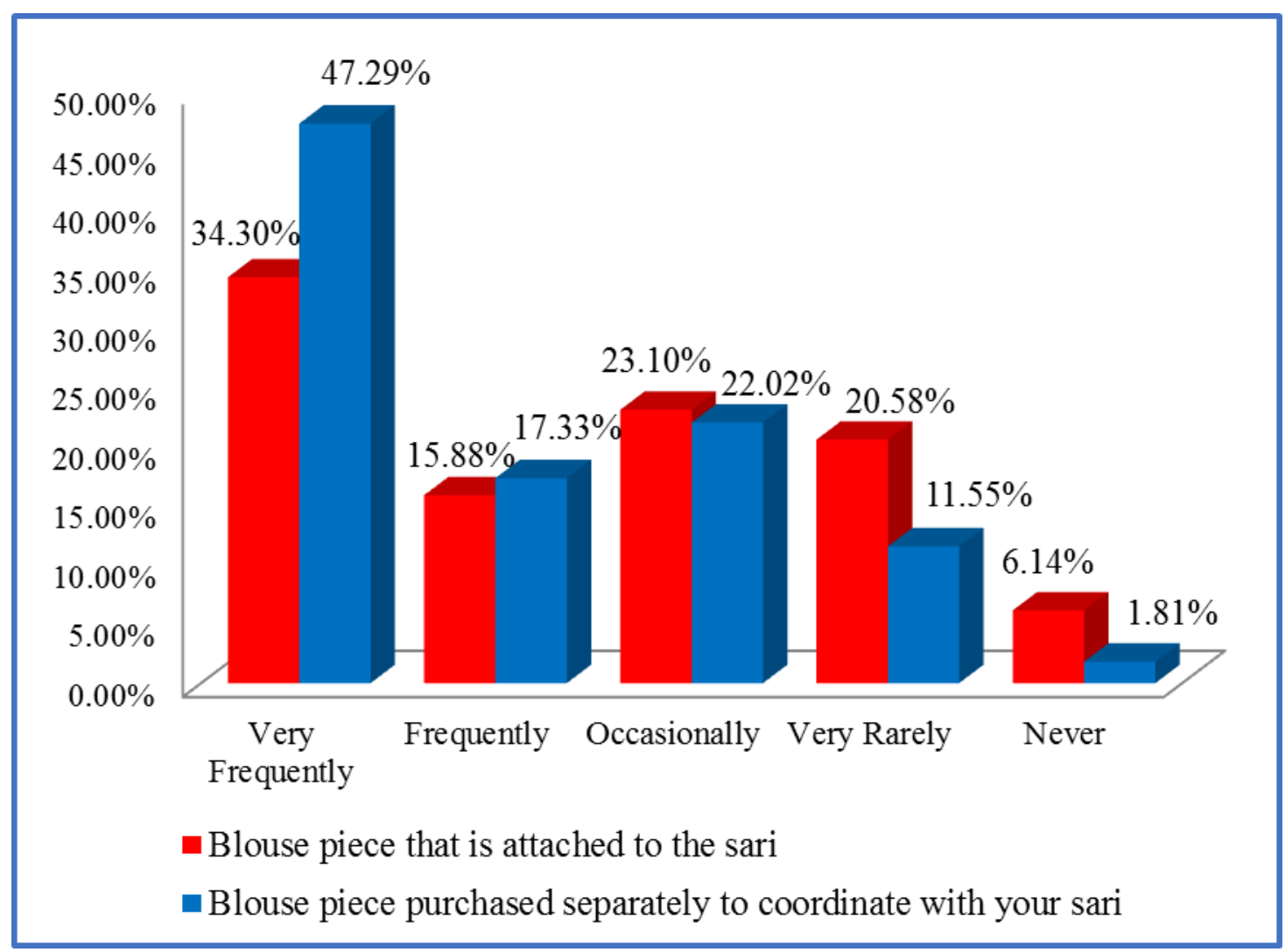

Figure 1.2: Preference for type of blouse piece

The sample's inclination to mix and match blouses with different saris is represented at Fig. 1.3. It is found out that $75.45 \%$ of the sari wearers mix and match their blouses with different saris.

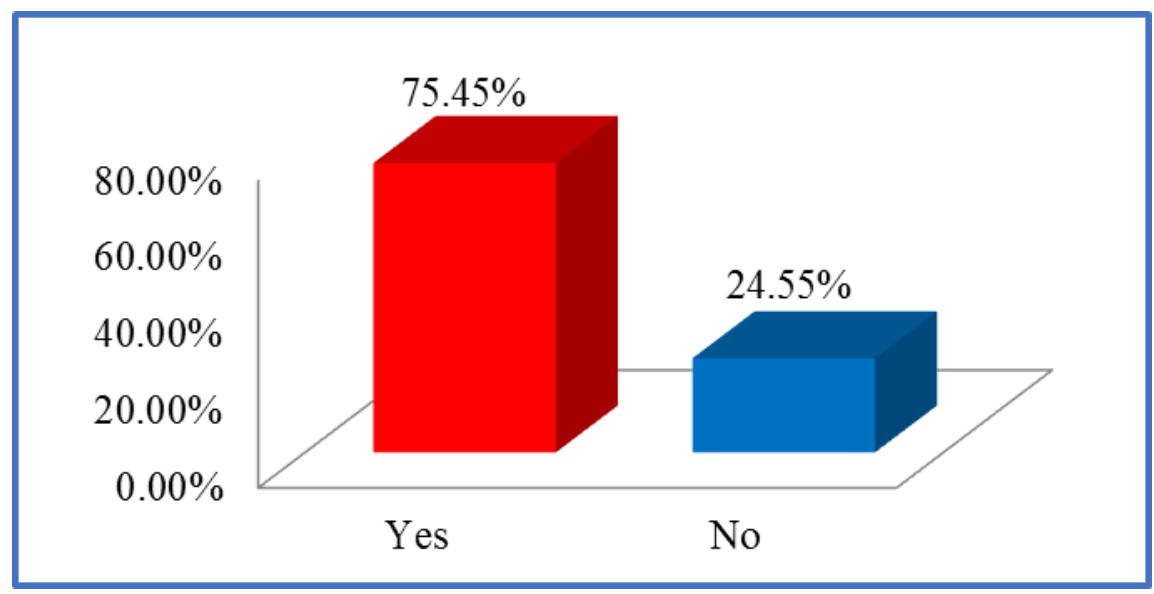

Figure 1.3: Preference for mix and match blouses

The respondents were asked to indicate their sources of reference to decide the styling of the sari blouse. Referring to Table 1.1, it is determined that sources of style reference that are very frequently visited by respondents include Bollywood and celebrity fashion $(25.27 \%)$ followed by tailor (15.88\%) and internet including social media $(15.52 \%)$. It is also indicated that the respondents frequently refer to magazines and newspapers $(26.71 \%)$ followed by social gatherings $(23.10 \%)$. It can be said that Bollywood and celebrity fashion, magazines and newspapers, tailor, internet and social gatherings are more significant sources of sari blouse reference in comparison to the others. Some of the respondents $(19.85 \%)$ also delineated that they prefer to self-design their sari blouse, according to their personal liking and style statement. 
Table 1.1: Sources of reference for sari blouse styles

\begin{tabular}{|l|c|c|c|c|c|}
\hline & Very Frequently & Frequently & Occasionally & Very Rarely & Never \\
\hline Tailor & $15.88 \%$ & $19.13 \%$ & $24.55 \%$ & $23.10 \%$ & $17.33 \%$ \\
\hline $\begin{array}{l}\text { Magazine \& } \\
\text { Newspapers }\end{array}$ & $8.66 \%$ & $26.71 \%$ & $36.10 \%$ & $15.16 \%$ & $13.36 \%$ \\
\hline $\begin{array}{l}\text { Internet / Social } \\
\text { Networking }\end{array}$ & $15.52 \%$ & $17.69 \%$ & $24.91 \%$ & $19.86 \%$ & $22.02 \%$ \\
\hline $\begin{array}{l}\text { Brochures of } \\
\text { stores / brands }\end{array}$ & $2.89 \%$ & $14.08 \%$ & $31.41 \%$ & $26.71 \%$ & $24.91 \%$ \\
\hline Fashion Shows & $7.22 \%$ & $15.16 \%$ & $22.02 \%$ & $22.02 \%$ & $33.57 \%$ \\
\hline $\begin{array}{l}\text { Bollywood / } \\
\text { Celebrity Fashion }\end{array}$ & $25.27 \%$ & $19.13 \%$ & $13.00 \%$ & $19.49 \%$ & $23.10 \%$ \\
\hline Television Serials & $6.14 \%$ & $9.03 \%$ & $22.74 \%$ & $24.55 \%$ & $37.55 \%$ \\
\hline Social gatherings & $9.39 \%$ & $23.10 \%$ & $38.63 \%$ & $13.36 \%$ & $15.52 \%$ \\
\hline
\end{tabular}

Table 1.2 delineates the distribution of respondents according to the expenditure incurred on the fabric and stitching of the sari blouse. It is observed that $53.07 \%$ of the sari wearers spend Rs.501 to Rs.750 and $40.43 \%$ of the sari wearers spend Rs. 751 to Rs. 1000 frequently. It is also ascertained that $42.96 \%$ of the sari wearers occasionally spend more than Rs.1000. It is established that the sari wearers frequently spend between Rs.500 and Rs. 1000 on their sari blouse, and on occasions spend more than Rs. 1000.

Table 1.2: Expenditure incurred on sari blouse

\begin{tabular}{|l|c|c|c|c|c|}
\hline & Very Frequently & Frequently & Occasionally & Very Rarely & Never \\
\hline Less than Rs. 500 & $7.22 \%$ & $16.25 \%$ & $11.19 \%$ & $45.85 \%$ & $19.49 \%$ \\
\hline Rs. 501 - Rs. 750 & $8.66 \%$ & $53.07 \%$ & $21.30 \%$ & $9.03 \%$ & $7.94 \%$ \\
\hline $\begin{array}{l}\text { Rs. 751 - Rs. 1000 } \\
\text { More than } \\
\text { Rs. 1000 }\end{array}$ & $10.83 \%$ & $40.43 \%$ & $32.49 \%$ & $9.03 \%$ & $7.22 \%$ \\
\hline
\end{tabular}

The sample indicated their fabric preference for the sari blouse in terms of fibre content and fabric. Table 1.3 designates distribution of respondents on the basis of their preference for different fibres. It is observed that $100 \%$ cotton is selected very frequently by $60.65 \%$ of the respondents. $100 \%$ silk and silk-cotton blend are selected occasionally by $46.21 \%$ and $41.16 \%$ of the respondents respectively. Thus $100 \%$ cotton is most preferred followed by $100 \%$ silk and silk-cotton blend.

Table 1.3: Preference for fibre content of sari blouse

\begin{tabular}{|l|l|l|l|l|l|}
\hline & Very Frequently & Frequently & Occasionally & Very Rarely & Never \\
\hline
\end{tabular}




\begin{tabular}{|l|c|c|c|c|c|}
\hline $\mathbf{1 0 0} \%$ Cotton & $60.65 \%$ & $23.47 \%$ & $6.86 \%$ & $4.69 \%$ & $4.33 \%$ \\
\hline Cotton - Polyester blend & $1.81 \%$ & $13.72 \%$ & $20.94 \%$ & $25.99 \%$ & $37.55 \%$ \\
\hline $\mathbf{1 0 0 \%}$ Polyester & $0.00 \%$ & $2.17 \%$ & $7.94 \%$ & $19.13 \%$ & $70.76 \%$ \\
\hline $\mathbf{1 0 0 \%}$ Silk & $12.27 \%$ & $31.41 \%$ & $46.21 \%$ & $7.58 \%$ & $2.53 \%$ \\
\hline Silk - Cotton blend & $8.30 \%$ & $30.69 \%$ & $41.16 \%$ & $10.11 \%$ & $9.75 \%$ \\
\hline Silk - Polyester blend & $1.81 \%$ & $9.39 \%$ & $25.63 \%$ & $24.55 \%$ & $38.63 \%$ \\
\hline
\end{tabular}

Table 1.4 displays respondents' preference for different fabrics, namely Rubia, Cambric, Poplin, Lizzy Bizzy, Velvet, Brocade, Tissue, Net/Lace, Satin, Crepe, Chiffon/Georgette and Hosiery. It is noted that Rubia $2 \mathrm{X} 2$ is selected very frequently by $40.07 \%$ of the respondents. Brocade and crepe are selected occasionally by $52.71 \%$ and $40.43 \%$ of the sari wearers respectively. It can be inferred that Rubia 2 X2 is most preferred frequently followed by occasional preference for brocade, crepe, net/lace, chiffon/georgette and tissue.

Table 1.4: Preference for fabric of sari blouse

\begin{tabular}{|l|c|c|c|c|c|}
\hline & Very Frequently & Frequently & Occasionally & Very Rarely & Never \\
\hline Rubia 2X2 & $40.07 \%$ & $18.41 \%$ & $11.19 \%$ & $16.61 \%$ & $13.72 \%$ \\
\hline Cambric & $2.17 \%$ & $6.86 \%$ & $15.16 \%$ & $25.63 \%$ & $50.18 \%$ \\
\hline Poplin & $1.08 \%$ & $3.97 \%$ & $11.91 \%$ & $23.83 \%$ & $59.21 \%$ \\
\hline Lizzy Bizzy & $1.08 \%$ & $7.58 \%$ & $12.64 \%$ & $22.74 \%$ & $55.96 \%$ \\
\hline Velvet & $0.36 \%$ & $7.94 \%$ & $28.16 \%$ & $23.10 \%$ & $40.43 \%$ \\
\hline Brocade / Jacquard & $6.14 \%$ & $19.49 \%$ & $52.71 \%$ & $15.52 \%$ & $6.14 \%$ \\
\hline Tissue & $2.17 \%$ & $5.78 \%$ & $32.13 \%$ & $25.63 \%$ & $34.30 \%$ \\
\hline Net / Lace & $1.81 \%$ & $10.47 \%$ & $35.02 \%$ & $21.66 \%$ & $31.05 \%$ \\
\hline Satin & $0.72 \%$ & $5.78 \%$ & $22.74 \%$ & $25.27 \%$ & $45.49 \%$ \\
\hline Crepe & $6.14 \%$ & $14.44 \%$ & $40.43 \%$ & $19.49 \%$ & $19.49 \%$ \\
\hline Chiffon / Georgette & $4.69 \%$ & $14.80 \%$ & $34.30 \%$ & $18.41 \%$ & $27.80 \%$ \\
\hline Hosiery & $0.72 \%$ & $2.17 \%$ & $13.00 \%$ & $19.13 \%$ & $64.98 \%$ \\
\hline
\end{tabular}

Table 1.5 denotes the preference of the respondents for the placket/opening of their sari blouse. It is observed that $67.51 \%$ of the sari wearers prefer the front open style very frequently, followed by occasional preference for back opening and side opening.

Table 1.5: Preference for placket opening of sari blouse

\begin{tabular}{|l|c|c|c|c|c|}
\hline & Very Frequently & Frequently & Occasionally & Very Rarely & Never \\
\hline Sari blouse with front opening & $67.51 \%$ & $10.47 \%$ & $9.39 \%$ & $7.22 \%$ & $5.42 \%$ \\
\hline
\end{tabular}


Consumer Preferences for Sari Blouse and Scope for Readymade Sari Blouse

\begin{tabular}{|l|c|c|c|c|c|}
\hline Sari blouse with back opening & $13.72 \%$ & $16.25 \%$ & $27.80 \%$ & $20.22 \%$ & $22.02 \%$ \\
\hline Sari blouse with side opening & $16.97 \%$ & $12.27 \%$ & $22.02 \%$ & $14.08 \%$ & $34.66 \%$ \\
\hline
\end{tabular}

The sample's preference for fastener of their sari blouse is represented in Table 1.6. It is examined that $71.84 \%$ of the sari wearers prefer hooks and eyes very frequently and the zipper and tie-strings are preferred occasionally by the sari wearers.

Table 1.6: Preference for fastener of sari blouse

\begin{tabular}{|l|c|c|c|c|c|}
\hline & Very Frequently & Frequently & Occasionally & Very Rarely & Never \\
\hline Hooks and eyes & $71.84 \%$ & $14.08 \%$ & $8.30 \%$ & $3.25 \%$ & $2.53 \%$ \\
\hline Buttons and loops & $2.89 \%$ & $9.03 \%$ & $12.27 \%$ & $24.91 \%$ & $50.90 \%$ \\
\hline Tie - strings & $4.33 \%$ & $13.00 \%$ & $25.27 \%$ & $24.19 \%$ & $33.21 \%$ \\
\hline Fabric bow-tie & $1.44 \%$ & $3.61 \%$ & $11.55 \%$ & $20.22 \%$ & $63.18 \%$ \\
\hline Zipper & $15.52 \%$ & $17.33 \%$ & $23.10 \%$ & $14.80 \%$ & $29.24 \%$ \\
\hline
\end{tabular}

Table 1.7 depicts the respondents' preference for the styling of their sari blouse. It is analysed that the basic sari blouse style is preferred very frequently by $77.98 \%$ of the respondents. It is also observed that a sizeable sample has never opted for off-shoulder $(80.51 \%)$, one-shoulder $(74.37 \%)$, corset style $(71.48 \%)$ and bustier $(70.40 \%)$. It can be inferred that the basic sari blouse is preferred most frequently, followed by occasional preference for raised neckline and halter neck styles.

Table 1.7: Preference for sari blouse style

\begin{tabular}{|l|c|c|c|c|c|}
\hline & Very Frequently & Frequently & Occasionally & Very Rarely & Never \\
\hline Basic Sari Blouse & $77.98 \%$ & $9.75 \%$ & $3.97 \%$ & $4.33 \%$ & $3.97 \%$ \\
\hline Raised Neckline & $11.55 \%$ & $22.74 \%$ & $28.88 \%$ & $19.86 \%$ & $16.97 \%$ \\
\hline Halter Neck & $2.17 \%$ & $8.66 \%$ & $20.22 \%$ & $20.22 \%$ & $48.74 \%$ \\
\hline Bustier & $1.81 \%$ & $5.05 \%$ & $5.78 \%$ & $16.97 \%$ & $70.40 \%$ \\
\hline One Shoulder & $0.36 \%$ & $2.53 \%$ & $6.14 \%$ & $16.61 \%$ & $74.37 \%$ \\
\hline Off Shoulder & $0.72 \%$ & $2.53 \%$ & $3.25 \%$ & $13.00 \%$ & $80.51 \%$ \\
\hline Corset Style & $1.44 \%$ & $3.61 \%$ & $11.91 \%$ & $11.55 \%$ & $71.48 \%$ \\
\hline
\end{tabular}

The distribution of respondents according to the preference for the back neck depth of the sari blouse is delineated in Table 1.8. It is observed that the medium neckline and low neckline are preferred very frequently by $44.04 \%$ and $43.68 \%$ of the respondents respectively. 
Table 1.8: Preference for back neck depth of sari blouse

\begin{tabular}{|l|c|c|c|c|l|}
\hline & Very Frequently & Frequently & Occasionally & Very Rarely & Never \\
\hline Close to the neck & $6.86 \%$ & $7.94 \%$ & $15.52 \%$ & $27.44 \%$ & $42.24 \%$ \\
\hline Medium & $44.04 \%$ & $18.05 \%$ & $12.27 \%$ & $14.44 \%$ & $11.19 \%$ \\
\hline Low & $43.68 \%$ & $24.55 \%$ & $20.94 \%$ & $6.86 \%$ & $3.97 \%$ \\
\hline Backless & $7.58 \%$ & $7.58 \%$ & $23.83 \%$ & $19.49 \%$ & $41.52 \%$ \\
\hline
\end{tabular}

Table 1.9 depicts the respondents' preference for sleeve length of the sari blouse. It is noted that the short sleeves are preferred very frequently by $48.38 \%$ of the sari wearers followed by half sleeves $(25.63 \%)$, sleeveless $(23.47 \%)$ and cap sleeves (22.74\%). Elbow length and three-quarter sleeves are preferred occasionally.

Table 1.9: Preference for sleeve length of sari blouse

\begin{tabular}{|l|c|c|c|c|c|}
\hline & Very Frequently & Frequently & Occasionally & Very Rarely & Never \\
\hline Sleeveless & $23.47 \%$ & $16.25 \%$ & $17.69 \%$ & $19.86 \%$ & $22.74 \%$ \\
\hline Cap Sleeves & $22.74 \%$ & $19.13 \%$ & $20.22 \%$ & $13.72 \%$ & $24.19 \%$ \\
\hline Short Sleeves & $48.38 \%$ & $22.38 \%$ & $15.16 \%$ & $6.50 \%$ & $7.58 \%$ \\
\hline Half Sleeves & $25.63 \%$ & $16.97 \%$ & $20.22 \%$ & $16.25 \%$ & $20.94 \%$ \\
\hline Elbow length Sleeves & $5.05 \%$ & $13.00 \%$ & $28.16 \%$ & $20.94 \%$ & $32.85 \%$ \\
\hline Three-quarter Sleeves & $3.97 \%$ & $9.75 \%$ & $20.22 \%$ & $26.35 \%$ & $39.71 \%$ \\
\hline Full Sleeves & $1.08 \%$ & $5.78 \%$ & $15.88 \%$ & $24.91 \%$ & $52.35 \%$ \\
\hline
\end{tabular}

\section{Descriptive Statistics of Preference for Readymade Sari Blouse}

The sample was asked if they had purchased a semi-stitched sari blouse and a readymade sari blouse. Fig. 1.4 displays that $34.66 \%$ of the sari wearers have purchased a semi-stitched sari blouse and $49.10 \%$ of the sari wearers have purchased a readymade sari blouse. It can be deduced that the consumers prefer ready-to-wear sari blouse over a semi-stitched option.

The respondents were also asked to indicate the reasons for not purchasing a readymade sari blouse. Many respondents specified that they have not tried out a readymade blouse as it would not provide a good fit. Some of the respondents expressed that sizing and fit become deterrents while purchasing a readymade sari blouse. However, respondents also indicated that ready-to-wear blouse is a convenient option provided the fit is good. 


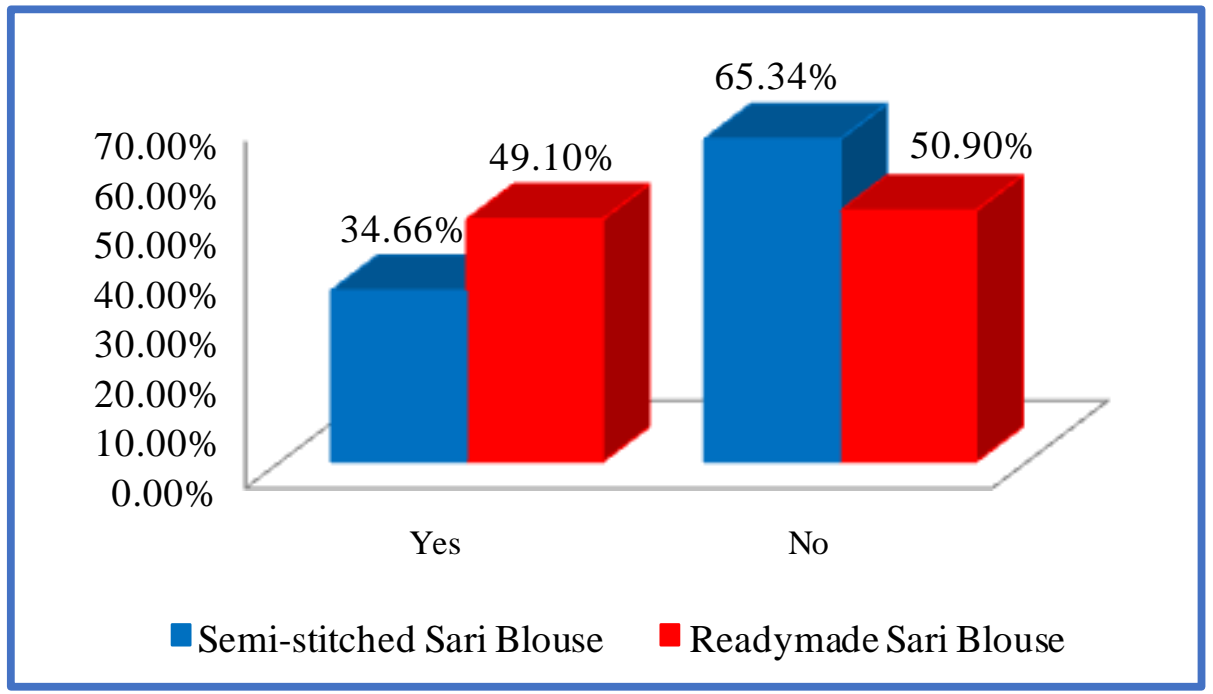

Figure 1.4: Purchase of semi-stitched and readymade sari blouse

The preferred retail options for buying a readymade sari blouse is delineated at Fig. 1.5. It is examined that $55.15 \%$ of the respondents purchase their readymade blouses from retail stores, $43.38 \%$ from local markets, $24.26 \%$ from multi designer stores and $18.38 \%$ from exclusive designer stores. A small percentage of $8.09 \%$ of the respondents have bought their readymade blouses from online stores.

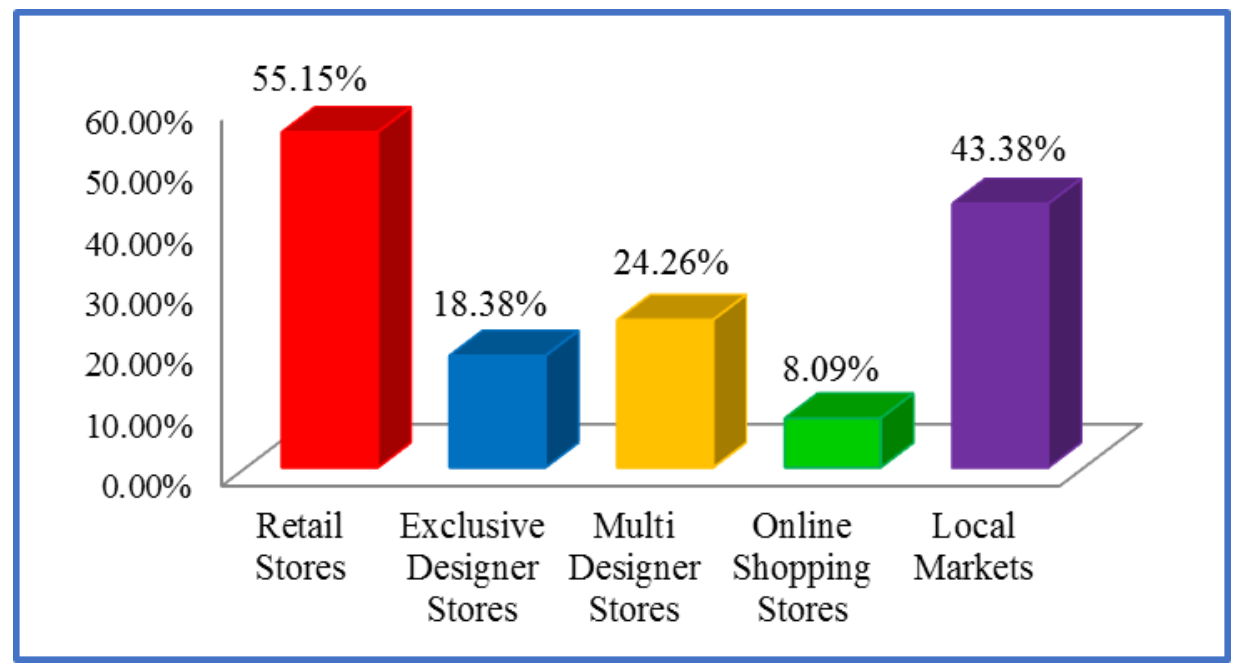

Figure 1.5: Retail options for readymade sari blouse

The wearers' satisfaction with the readymade sari blouse is described at Fig. 1.6. It is observed that $60.29 \%$ of the respondents are not satisfied with their readymade sari blouse. The primary reasons ascribed by the respondents are fitting and sizing concerns, limited availability of styles and quality concerns in terms of fabric and stitching. Many of the respondents expressed that though readymade blouse is a good option, the fitting problems and need for alteration become a limitation. Some of the respondents also stated that there could be more variety in blouse designs. 


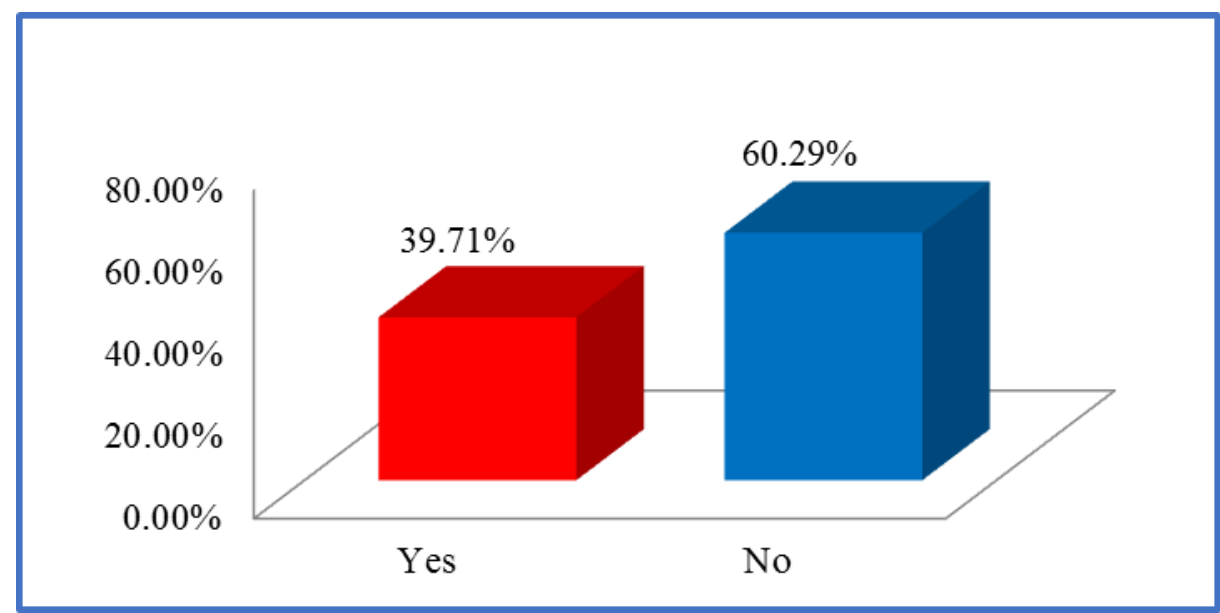

Figure 1.6: Satisfaction with the readymade sari blouse

The important factors kept in mind by the respondents while selecting a sari blouse is portrayed in Table 1.10. It is examined that $90.97 \%$ of the respondents give most importance to fit and comfort while choosing a sari blouse, followed by fabric quality $(76.53 \%)$ and style $(68.95 \%)$. It can be said that fit and comfort, fabric quality and style are key factors that influence consumer buying behaviour for sari blouse.

Table 1.10: Important factors for selecting sari blouse

\begin{tabular}{|l|c|c|c|c|c|}
\hline & $\begin{array}{c}\text { Extremely } \\
\text { Important }\end{array}$ & Somewhat & Neutral & Not very & Not at all \\
& $\mathbf{( 1 )}$ & $\mathbf{( 2 )}$ & $\mathbf{( 3 )}$ & $\mathbf{( 4 )}$ & $\mathbf{( 5 )}$ \\
\hline Style & $68.95 \%$ & $23.10 \%$ & $6.50 \%$ & $0.72 \%$ & $0.72 \%$ \\
\hline Fabric Quality & $76.53 \%$ & $21.30 \%$ & $2.17 \%$ & $0.00 \%$ & $0.00 \%$ \\
\hline Fit \& Comfort & $90.97 \%$ & $7.22 \%$ & $1.08 \%$ & $0.36 \%$ & $0.36 \%$ \\
\hline Durability & $41.88 \%$ & $40.43 \%$ & $14.80 \%$ & $2.53 \%$ & $0.36 \%$ \\
\hline Wash Care & $37.55 \%$ & $37.55 \%$ & $16.61 \%$ & $7.22 \%$ & $1.08 \%$ \\
\hline Price & $27.08 \%$ & $43.68 \%$ & $22.38 \%$ & $5.78 \%$ & $1.08 \%$ \\
\hline
\end{tabular}

\section{Crosstab Analysis and Chi-Square Tests}

Cross-tabulations were carried out to determine the association between the age group of the sari wearers and variables like frequency of wearing the sari, importance of the sari blouse in relation to the sari, purchase of readymade sari blouse and preference for tailor-made, semi-stitched and readymade sari blouse. The chi-square and Cramer's V values are presented in Table 1.11. It is indicated that there is no significant association between age and importance for the sari blouse. It is ascertained that across age groups the sari blouse is given as much importance as the sari. However, there is a significant relationship between age and other factors like frequency of wearing the sari, purchase of readymade sari blouse, preference for tailor-made, semi-stitched and readymade sari blouse, plain and decorative blouse, matching coloured and contrasting coloured blouse, blouse piece attached to the sari and blouse piece purchased separately to coordinate with the sari. 
Table 1.11: Association between age and preference for sari blouse

\begin{tabular}{|c|c|c|c|c|c|c|}
\hline \multirow{2}{*}{ Variables } & \multicolumn{3}{|c|}{ Chi-Square } & \multicolumn{2}{|c|}{ Cramer's V } & \multirow{2}{*}{$\begin{array}{c}\mathbf{H}_{0}: \\
\text { Rejected/Accepted }\end{array}$} \\
\hline & Value & df & $\begin{array}{l}\text { Asymp. } \\
\text { Sig. (2- } \\
\text { sided) }\end{array}$ & Value & $\begin{array}{l}\text { Approx. } \\
\text { Sig. }\end{array}$ & \\
\hline $\begin{array}{l}\text { Frequency of } \\
\text { wearing the sari }\end{array}$ & 95.674 & 15 & .000 & .339 & .000 & Rejected \\
\hline $\begin{array}{l}\text { Importance for } \\
\text { the sari blouse }\end{array}$ & 14.401 & 9 & .109 & . 132 & .109 & Accepted \\
\hline $\begin{array}{l}\text { Purchase of } \\
\text { readymade sari } \\
\text { blouse }\end{array}$ & 9.304 & 3 & .026 & .183 & .026 & Rejected \\
\hline $\begin{array}{l}\text { Tailor-made sari } \\
\text { blouse }\end{array}$ & 65.432 & 12 & .000 & .281 & .000 & Rejected \\
\hline $\begin{array}{l}\text { Semi-stitched } \\
\text { sari blouse }\end{array}$ & 29.598 & 12 & .003 & .189 & .003 & Rejected \\
\hline $\begin{array}{l}\text { Readymade sari } \\
\text { blouse }\end{array}$ & 85.426 & 12 & .000 & .321 & .000 & Rejected \\
\hline Plain blouse & 43.883 & 12 & .000 & .230 & .000 & Rejected \\
\hline $\begin{array}{l}\text { Decorative } \\
\text { blouse }\end{array}$ & 41.966 & 12 & .000 & .225 & .000 & Rejected \\
\hline $\begin{array}{l}\text { Matching } \\
\text { coloured blouse }\end{array}$ & 58.975 & 12 & .000 & .266 & .000 & Rejected \\
\hline $\begin{array}{l}\text { Contrasting } \\
\text { coloured blouse }\end{array}$ & 43.120 & 12 & .000 & .228 & .000 & Rejected \\
\hline $\begin{array}{l}\text { Blouse piece } \\
\text { attached to sari }\end{array}$ & 35.969 & 12 & .000 & .208 & .000 & Rejected \\
\hline $\begin{array}{l}\text { Blouse piece } \\
\text { purchased } \\
\text { separately }\end{array}$ & 39.284 & 12 & . 000 & 217 & .000 & Rejected \\
\hline
\end{tabular}

Cross-tabulations were also conducted to analyse the association between age and preference for sari blouse in terms of fabrics and styling, including plackets and fasteners. The chi-square and Cramer's V values are displayed in Table 1.12. It is determined that primarily among the fibres preferred for sari blouse, there is no significant association between age and preference for fibres like cotton/polyester blend, $100 \%$ silk, 100\% Polyester and silk/cotton blend. Though a significant relationship is established between age and fibre types like $100 \%$ cotton and silk/polyester blend. Similarly there is no significant association between age and fabrics like Cambric, Poplin, Lizzy Bizzy, Tissue, Satin, Crepe, Chiffon/Georgette and Hosiery. However there is significant relationship between age and fabric varieties like Rubia, Velvet, Brocade and Net/Lace. The results confirm that there is a significant relationship between age and preference for sari blouse styling that includes placket opening, type of fastening and sleeve lengths. It is also demonstrated that there is a significant 
association between age and back neck depth preference including medium neck and backless, whereas there is no significance between age and preference for low neck and close neck options.

Table 1.12: Association between age and preference for sari blouse fabrics and styling

\begin{tabular}{|c|c|c|c|c|c|c|}
\hline \multirow{2}{*}{ Variables } & \multicolumn{3}{|c|}{ Chi-Square } & \multicolumn{2}{|c|}{ Cramer's V } & \multirow{2}{*}{$\begin{array}{c}\mathrm{H}_{0}: \\
\text { Rejected/Accepted }\end{array}$} \\
\hline & Value & df & $\begin{array}{l}\text { Asymp. Sig. } \\
\text { (2-sided) }\end{array}$ & Value & $\begin{array}{l}\text { Approx. } \\
\text { Sig. }\end{array}$ & \\
\hline $100 \%$ Cotton & 25.206 & 12 & .014 & .174 & .014 & Rejected \\
\hline Cotton-Polyester blend & 15.067 & 12 & .238 & .135 & .238 & Accepted \\
\hline $100 \%$ Polyester & 10.180 & 12 & .336 & .111 & .336 & Accepted \\
\hline $100 \%$ Silk & 17.174 & 12 & .143 & .144 & .143 & Accepted \\
\hline Silk-Cotton blend & 4.201 & 12 & .980 & .071 & .980 & Accepted \\
\hline Silk-Polyester blend & 23.140 & 12 & .027 & .167 & .027 & Rejected \\
\hline Rubia 2X2 & 49.437 & 12 & .000 & .244 & .000 & Rejected \\
\hline Cambric & 11.727 & 12 & .468 & .119 & .468 & Accepted \\
\hline Poplin & 16.736 & 12 & .160 & .142 & .160 & Accepted \\
\hline Lizzy Bizzy & 13.352 & 12 & .344 & .127 & .344 & Accepted \\
\hline Velvet & 53.205 & 12 & .000 & .253 & .000 & Rejected \\
\hline Brocade & 25.116 & 12 & .014 & .174 & .014 & Rejected \\
\hline Tissue & 10.904 & 12 & .537 & .115 & .537 & Accepted \\
\hline Net/lace & 50.022 & 12 & .000 & .245 & .000 & Rejected \\
\hline Satin & 15.561 & 12 & .212 & .137 & .212 & Accepted \\
\hline Crepe & 17.661 & 12 & .126 & .146 & .126 & Accepted \\
\hline Chiffon / Georgette & 14.653 & 12 & .261 & .133 & .261 & Accepted \\
\hline Hosiery & 4.325 & 12 & .977 & .072 & .977 & Accepted \\
\hline Front opening & 57.617 & 12 & .000 & .263 & .000 & Rejected \\
\hline Back opening & 48.815 & 12 & .000 & .242 & .000 & Rejected \\
\hline Side opening & 68.698 & 12 & .000 & .288 & .000 & Rejected \\
\hline Hooks \& eyes & 34.347 & 12 & .001 & .203 & .001 & Rejected \\
\hline Buttons \& loops & 25.192 & 12 & .014 & .174 & .014 & Rejected \\
\hline
\end{tabular}




\begin{tabular}{|c|c|c|c|c|c|c|}
\hline Tie-strings & 38.788 & 12 & .000 & .216 & .000 & Rejected \\
\hline Fabric bow-tie & 31.226 & 12 & .002 & .194 & .002 & Rejected \\
\hline Zipper & 76.526 & 12 & .000 & .303 & .000 & Rejected \\
\hline Basic & 36.370 & 12 & .000 & .209 & .000 & Rejected \\
\hline Raised neckline & 30.337 & 12 & .002 & .191 & .002 & Rejected \\
\hline Halter & 63.284 & 12 & .000 & .276 & .000 & Rejected \\
\hline Bustier & 40.093 & 12 & .000 & .220 & .000 & Rejected \\
\hline One-shoulder & 42.956 & 12 & .000 & .227 & .000 & Rejected \\
\hline Off shoulder & 35.082 & 12 & .000 & .205 & .000 & Rejected \\
\hline Corset & 64.658 & 12 & .000 & .279 & .000 & Rejected \\
\hline Close to neck & 12.772 & 12 & .386 & .124 & .386 & Accepted \\
\hline Medium & 28.516 & 12 & .005 & .185 & .005 & Rejected \\
\hline Low & 18.111 & 12 & .112 & .148 & .112 & Accepted \\
\hline Backless & 69.669 & 12 & .000 & .290 & .000 & Rejected \\
\hline Sleeveless & 28.753 & 12 & .004 & .186 & .004 & Rejected \\
\hline Cap sleeves & 36.381 & 12 & .000 & .209 & .000 & Rejected \\
\hline Short sleeves & 30.275 & 12 & .003 & .191 & .003 & Rejected \\
\hline Half sleeves & 44.519 & 12 & .000 & .231 & .000 & Rejected \\
\hline Elbow length sleeves & 29.415 & 12 & .003 & .188 & .003 & Rejected \\
\hline Three-quarter sleeves & 26.458 & 12 & .009 & .178 & .009 & Rejected \\
\hline Full sleeves & 22.471 & 12 & .033 & .164 & .033 & Rejected \\
\hline
\end{tabular}

IV.

CONCLUSION

The inferences drawn from the consumer survey are presented below.

- The study indicated that the younger unmarried women preferred sari as an attire mostly for occasional wear and women in the age group of 40 years and above gave preference to sari for regular wear. It is inferred that sari as a dress has socio-cultural significance in India, mostly favoured by married women.

- Considering that majority of the respondents were working professionals, it is interpreted that professionals in distinctive sectors like education, hospitality, health and media consider sari suitable for work wear. 
- It was observed that majority of the respondents across age groups considered the blouse as important as the sari and some gave more importance to the blouse than the sari. It is determined that the urban sari wearers are laying emphasis on the blouse, to accentuate their sari ensemble.

- It was ascertained that the consumers frequently referred to Bollywood or celebrity fashion and magazines and newspapers for design ideas of their sari blouse, followed by tailor, relevant websites including social networking sites and social get-togethers. The preference for Bollywood and celebrity fashion as a source of inspiration for sari blouse styling confirms the pre-eminent role of Bollywood stars as fashion leaders who set the trends and thus have influenced the sari blouse styles over the years. The survey also indicates that consumers keep in mind personal liking and individual style statement, while deciding the styling of their blouse.

- Considering the respondents' preference for plain and decorative sari blouses, it was determined that sari wearers in the age group of 40 years and above mostly preferred plain blouses and occasionally favoured decorative blouses. The sari wearers in the age group of 20-29 years mostly favoured decorative blouses.

- The survey displayed that respondents in the age group of 40 years and above mostly selected matching coloured blouses and occasionally favoured contrasting coloured blouses. The sari wearers in the age group of 20-29 years mostly selected contrasting coloured blouses.

- Keeping in view the respondents' preference for type of blouse piece, it is inferred that the urban sari wearers in the age group of 20-39 years are inclined to purchase blouse piece separately to coordinate with the sari. Though consumers continue to prefer blouse piece attached to the sari, there could be a gradual shift towards procuring a separate blouse piece to match with the sari, as the survey indicated consumer preference for mix and match blouses with different saris.

- Regarding the expenditure entailed on the blouse (fabric + stitching), the survey indicated that sari wearers usually spend between Rs.500 and Rs.1000, and occasionally spend more than Rs.1000.

- Regarding the fibre and fabric preference for the sari blouse, the survey pointed out to $100 \%$ cotton as the most favoured fibre, followed by $100 \%$ silk and silk-cotton blend. It was determined that Rubia 2 X2 was selected most frequently and fabrics like brocade, crepe and chiffon/georgette, net/lace and tissue were opted occasionally. It was examined that the young sari wearers aged 20-29 years showed willingness to try out fabrics like velvet and net/lace for occasional wear while the wearers aged 30 years and above selected brocade occasionally for their blouse.

- The survey displayed that sari blouse with front opening was preferred most frequently by sari wearers in the age group of 30 years and above. Among the younger age group, majority for a specific blouse opening was not observed, preferring front opening, back opening and side opening as well. With regards to the fasteners for the sari blouse, the hooks and eyes were usually preferred by majority of the sari wearers aged 30 years and above. Among the younger age group, preference for a particular fastener for the blouse was not evident, however hooks and eyes, zipper and tie-strings were given preference over buttons and loops and fabric bowtie.

- It was examined that most of the sari wearers in the age group of 30 years and above preferred basic sari blouse style. The younger sari wearers frequently preferred basic sari blouse and some occasionally selected raised neckline, halter and corset blouse styles. Some of the very revealing styles like off-shoulder and oneshoulder designs were selected by a very small percentage of the wearers. It is evident that mostly Indian women favour the conventional sari blouse. The experimental and very bold sari blouse designs are perhaps limited till the ramp, gaining attention of the global audience.

- It was surveyed that low and medium back neck depths were selected often and backless and close neck styles were picked occasionally. Across age groups, medium neckline was favoured frequently by sari wearers aged 30 years and above and low neckline was selected by some of the wearers in the age group of 20 to 39 years.

- The survey indicated that most of the sari wearers in the age group of 30 years and above preferred short sleeves. Among the age group of 20-39 years, few favoured sleeveless, cap sleeves and elbow length sleeves. The three-quarter and full length sleeves did not find favour among the older age group.

- The impact of age of the wearer on the sari blouse preferences is evident. It is inferred that the older women are conforming to the typical sari blouse with front opening, and hooks and eyes, whereas the younger women are keen to experiment with the fabric and styling of the sari blouse.

- The survey indicated that nearly half of the sample had purchased a readymade sari blouse whereas a smaller percentage had bought a semi-stitched blouse. It is deduced that consumers prefer readymade sari blouse over a semi-stitched sari blouse. The sari wearers who had not purchased a readymade sari blouse indicated fit and sizing as major limitations.

- It was found that primarily respondents in the age group of 20-29 years followed by 30-49 years had bought a readymade sari blouse. 
- It was determined that the sari wearers belonging to the older age group of 50 years and above gave most preference to tailor-made blouse whereas sari wearers in the age group of 20-39 years, and a lesser percentage from 40-49 years were more inclined for a readymade sari blouse.

- It was determined that both regular and occasional sari wearers were motivated to buy ready-to-wear sari blouses.

- It was examined that majority of the respondents had purchased their readymade blouse from retail stores and local markets.

- The survey displayed that majority of the respondents were dissatisfied with their readymade sari blouse. The major reasons stated by the respondents were fitting and sizing concerns, limited choice of blouse styles and quality issues with fabric and stitching. The sari wearers were of the view that the readymade sari blouse could be a good alternative to the custom-stitched blouse, provided the fitting problems could be addressed. There was a need felt for a wider range in blouse designs.

- As per the survey, fit and comfort, fabric quality and style are important factors that influence consumer buying behaviour for sari blouse.

Based on the conclusions drawn from the study, recommendations are suggested for designers, sari blouse manufacturers and retailers in an attempt to assist them in planning their design and marketing strategies for retailing ready-to-wear sari blouses for the consumers in Delhi/NCR.

- Keeping in view the importance accorded to the sari blouse by consumers, it would be beneficial to retail ready-to-wear blouses at sari stores in order to make it convenient for the consumers to coordinate the blouse with their sari, thus providing a one-stop solution.

- Taking into account varying preferences for sari blouse styles across age groups, retailers should offer conventional and classic as well as contemporary and innovative blouse styles.

- While designing and developing sari blouses, designers and manufacturers should keep in mind fit, comfort, fabric quality and style parameters.

- The major limitation of the ready-to-wear apparel industry is related to fit and sizing, thus need for alterations and overall dissatisfaction among the consumers. The fitting problem is more prominent in the case of close fitting garments like sari blouse. The designers and manufacturers should incorporate adjustable features in the blouse style to fit a larger number of women with varying body types. An effort should be made to resolve fit concerns faced by readymade sari blouse wearers.

- The lack of a standard sizing chart for Indian women is another concern that needs to be taken up by designers, garment manufacturers, retailers as well as academicians in fashion schools and research scholars. Considering the regional diversity within India, body sizing appears to be the main challenge faced by the garment industry. The need of the hour is to conduct an extensive anthropometric survey on Indian women, which can be carried out only with the support of educational institutes, garment technology enterprises and retail organisations.

\section{REFERENCES}

[1] Ghurye, G., Indian Costume (Bombay: Bombay Popular Prakashan, 1951).

[2] Flynn, D., Costumes of India (New Delhi: Oxford \& IBH Publishing Co., 1985).

[3] Gugnani, A. \& Brahma, K. P., The Ethnicwear Market in India. Images Business of Fashion, November, 2014, pp. 55-60. 